Maria M. Boużyk

Uniwersytet Kardynała Stefana Wyszyńskiego w Warszawie

\title{
MYŚl PEDAGOGICZNA JACKA (ADAMA) WORONIECKIEGO W WYBRANYCH PUBLIKACJACH Z OKRESU 1903-1918
}

[The pedagogical thought of Jacek (Adam) Woroniecki in selected works: 1903-1918]

Summary: This study examines whether the Jacek (Adam) Woroniecki's works (1903-1918) allow us to regard him as an influential pedagogue and educationist. The study consists of four parts. Part 1 , which precedes the main analysis, deals with Woroniecki's pedagogical abilities and qualifications. Parts 2, 3 and 4 survey successively the pedagogical core of Woroniecki's works, particularly some of his pedagogical ideas and his philosophical (i.e. Thomistic) approach to pedagogical issues. The findings are: a) at the pedagogical core of Woroniecki's works is an ethical approach to social problems, b) Woroniecki's ideas call for the harmonization of pedagogical and educational elements in human development and for the inclusion of religion, national culture and social patterning in this process, c) Woroniecki's pedagogics are founded on Thomism, as evidenced by his analytical approach and metaphysical, epistemological and anthropological premises.

Keywords: Polish Catholic pedagogy, upbringing, education, moral skills (virtues), Thomism

W kryterium czasowym zaproponowanym uczestnikom seminarium Myśl o wychowaniu dla Polski Niepodlegtej 1863/1914/18 dostrzegliśmy możliwość spojrzenia na treści obecne w publikacjach Jacka (Adama) Woronieckiego do 1918 roku jako na zaczyn późniejszej pracy pisarskiej tego myśliciela i zapowiedź roli, jaką miał on odegrać w polskiej pedagogice okresu międzywojnia. Przystępując do analizy w ten sposób wyselekcjonowanych tekstów, kierowaliśmy się chęcią uzupełnienia poruszanych na seminarium tematów: żaden z uczestników seminarium nie poświęcił temu pedagogowi uwagi. Tymczasem w jego dorobku pisarskim z lat 1903-1918 kwestie wychowania pojawiają się na tyle często, że można, naszym zdaniem, nazwać go nie tylko narodowym publicystą o dużej wrażliwości społecznej, ale już pedagogiem. 
Nasze analizy zostaną podzielone na cztery części. Najpierw przedstawimy krótki rys biograficzny, w którym zastanowimy się nad pedagogicznymi kompetencjami Woronieckiego. Następnie w jego tekstach spróbujemy wskazać obecność problematyki pedagogicznej oraz odczytać główne tezy pedagogiczne autora, a na koniec zajmiemy się charakterystycznym - tomistycznym - rysem pedagogiki Woronieckiego. W częściach pierwszej i drugiej będą nas interesowały kwestie historyczne: chcemy patrzeć na obecność pedagogicznej problematyki w pismach Woronieckiego jako na wyraz aktualnych w jego czasach potrzeb społecznopolitycznych. Natomiast w częściach trzeciej i czwartej podejmiemy próbę odczytania ponadczasowych walorów twórczości Woronieckiego.

Zaznaczmy, że $\mathrm{w}$ związku $\mathrm{z}$ przyjętymi na seminarium ramami czasowymi (1863-1918) będziemy mieć do czynienia $\mathrm{z}$ niewielką, w tym z bardzo wczesną, częścią ogromnego dorobku Woronieckiego, to jest z pracami, które napisał on w latach 1903-1918, a więc między 25. a 40. rokiem życia. Część prac jest sygnowana imieniem Adam, a część powstała po 14 września 1909 - imieniem zakonnym Jacek. Pod tym drugim imieniem Woroniecki jest rozpoznawany w literaturze fachowej.

\section{Pedagogiczne kompetencje Woronieckiego w świetle biografii: lata $1903-1918$}

Naszą analizę, jak wspomnieliśmy, zaczynamy od rozpatrzenia problemu pedagogicznych kompetencji Woronieckiego w świetle najbardziej znaczących faktów z jego życiorysu1. Oczywiście wybieramy z jego życia tylko okres, w którym zostały opublikowane interesujące nas teksty. Zaznaczmy przy tym, że pierwszy tekst Woronieckiego, datowany na rok 1903, ukazal się drukiem, gdy był on studentem Wydziału Teologicznego Uniwersytetu we Fryburgu, a ostatni, który będziemy rozważać, to artykuł publikowany na łamach listopadowego numeru krakowskiego miesięcznika „Rok Polski” w 1918 roku. Mamy więc do czynienia z piętnastoletnim okresem twórczości pisarskiej.

W świetle całej biografii Woronieckiego nie sposób nie zauważyć, że właśnie $\mathrm{w}$ okresie wybranym do naszej analizy przechodzi on formację intelektualną i duchową, która znacząco łączy się z nabywaniem kwalifikacji pedagogicznych. Odnotujmy przede wszystkim, że odbywa kilkuetapowe

\footnotetext{
${ }^{1}$ Wszystkie informacje biograficzne podajemy za dwiema publikacjami M.L. Niedzieli. Zob. tegoż, Kalendarium $i$ życie $i$ działalność ojca Jacka Woronieckiego, w: Stuga Boży ojciec Jacek Woroniecki uczy, red. tegoż, Warszawa 2006, s. 13-38. Zob. także: tegoż, Jacek Woroniecki OP $i$ jego troska o nowa świadomość chrześcijaństwa w Polsce, w: Człowiek - moralność wychowanie. Życie i myśl Jacka Woronieckiego OP, red. J. Gałkowski, M.L. Niedziela OP, Lublin 2000, s. 59-79.
} 
studia w dziedzinie nauk przyrodniczych (Fryburg) i teologicznych (Fryburg, Lublin, Rzym), które obejmują bardzo szeroki i zróżnicowany zakres wiedzy, istotny dla wyrobienia u niego, przyszłego pedagoga, niejednostronnego obrazu człowieka ${ }^{2}$. Woroniecki $\mathrm{w}$ czasie studiów ma okazję poznawać najnowsze trendy $\mathrm{w}$ badaniach antropologicznych takie jak: psychologizm, socjologizm, materializm.

Zaznaczmy również, że w omawianym przez nas okresie Woroniecki zdobywa doświadczenia w pracy nauczycielskiej, akademickiej i administracyjnej, co jest nie bez znaczenia dla ksztaltowania jakże charakterystycznego dla niego, realistycznego, praktycznego i twórczego spojrzenia na sprawy oświaty i wychowania. Dodajmy jeszcze, że dzięki długim zagranicznym pobytom (Szwajcaria, Francja, Holandia, Niemcy, Włochy) Woroniecki miał możliwość poznawania kultury innych narodów, a w ten sposób nabywał dystansu, potrzebnego do oceny aktualnych potrzeb edukacyjnych polskiego społeczeństwa ${ }^{3}$. Za granicą, jak możemy przypuszczać, doskonalił swoją znajomość języków obcych. Później wielokrotnie wykorzystywał ją w swojej pracy oświatowej. Każdy kto czyta jego Przewodnik po literaturze religijnej dla osób pragnacych pogłębić swe wykształcenie $w$ dziedzinie wiary katolickiej (1914), musi dostrzec, że walory edukacyjne tego studium pozostają $\mathrm{w}$ ścisłym związku z kompetencjami językowymi autora ${ }^{4}$.

Podkreślmy, że w czasie, w którym publikowane były omawiane przez nas teksty, Woroniecki podejmował ważne decyzje życiowe dotyczące swojego powołania kapłańskiego i zakonnego. Odcisnęły się one na jego całej pracy pisarskiej i nadały jego tekstom szczególny rys zatroskania o życie duchowe wychowanków5. Religia będzie pojmowana przez Woronieckiego jako ogniskowa kultury w ogóle, a kultury narodowej w szczególności.

Rozeznawanie powołania najprawdopodobniej przypadło na czas studiów we Fryburgu (1899-1905). Młody Woroniecki zetknął się wtedy ze środowiskiem dominikańskim. Zauważmy, za Maurycym L. Niedzielą $\mathrm{OP}^{6}$,

${ }^{2}$ Zob. na przykład tegoż, Spoleczeństwo a wychowanie, „Rok Polski” 1916, nr 8, s. 17-31; tegoż, O przysztość ruchu skautowego w Polsce, „Rok Polski 1918, nr 7-8, s. 451-467.

${ }^{3}$ Zob. obecne w niektórych tekstach Woronieckiego porównania, na przykład tegoż, Przewodnik po literaturze religijnej dla osób pragnących pogłębić swe wykształcenie $w$ dziedzinie wiary katolickiej, Lwów-Włocławek 1914; tegoż, Szkoła narodowa a nauczanie języka polskiego, „Rok Polski”, 1916, nr 1, s. 29-43; tegoż, Spoteczeństwo..., dz. cyt.; tegoż, Uczeń i książka, „Rok Polski” 1918, nr 11, s. 696-706.

${ }^{4}$ Zob. J. Woroniecki, Przewodnik..., dz. cyt.

${ }^{5}$ Zob. na przykład pochodzący z omawianego przez nas okresu tekst Woronieckiego O stosunku moralności do religii, „Wiadomości Archidiecezjalne Warszawskie” 1911, nr 3-4, s. 54-63; nr 5-6, s. 99-107.

${ }^{6}$ Zob. M. Niedziela, Kalendarium..., dz. cyt., s. 37. 
postulatorem $\mathrm{w}$ procesie beatyfikacyjnym Woronieckiego, że kontakt z tym środowiskiem musiał być znaczący, bo Woroniecki prawdopodobnie myślał o wyborze nie tylko stanu duchownego, ale i zakonnej drogi życia. Możemy przypuszczać, że jego plany nie były po myśli ojca, księcia Mieczysława, bo do zakonu dominikanów wstąpił dopiero po jego śmierci. Maurycy L. Niedziela wyjaśnia: „(...) książę Mieczysław szykował najstarszego syna na swego dziedzica, kształcąc go i wprowadzając do układów politycznych. Mógł go widzieć jako biskupa lubelskiego, ale nie jako zakonnika"7.

Fakty biograficzne oddające dynamikę procesu rozeznawania powołania są następujące: pobyt w rzymsko-katolickim seminarium duchownym w Lublinie (1905-1906), święcenia kapłańskie (1906), prowadzenie wykładów w lubelskim seminarium i pełnienie między innymi funkcji sekretarza biskupa (1906-1907), powrót do Fryburga i praca nad rozprawą doktorską (1907-1909).

W październiku 1908 roku Woroniecki napisał Raport o stanie ducha wobec zagadnień swojej przyszłości, a w niecały rok później rozpoczął nowicjat w zakonie dominikanów w klasztorze San Domenico da Fiesole (1909-1910). Profesję czasową złożył w roku 1910 (Rzym), a w następnym roku - śluby wieczyste (Düsseldorf, 1911). W latach 1907-1910 nie ukazały się drukiem żadne prace Woronieckiego. Pierwszy po przerwie tekst został opublikowany na łamach „Wiadomości Archidiecezjalnych Warszawskich” w 1911 roku i był poświęcony relacji religii oraz moralności ${ }^{8}$.

Władze zakonne powierzyły Woronieckiemu ważne zadania, między innymi misję utworzenia nowej prowincji dominikanów w Petersburgu (plany pokrzyżował wybuch I wojny światowej) oraz restauracji dawnej prowincji polskiej pod zaborem rosyjskim (Woroniecki był postrzegany przez władze zakonu jako główna postać w przeprowadzaniu reformy ${ }^{9}$ ). Od roku 1914 do 1919 Woroniecki przebywał w klasztorze dominikanów w Krakowie. W tym okresie prowadził wykłady z etyki, był czujnym obserwatorem życia społecznopolitycznego i dużo publikował. Wyprzedzając wnioski płynące z dalszych naszych analiz, spróbujmy zauważyć, że spełnianie się $\mathrm{w}$ kapłańskim i zakonnym powołaniu dokonuje się u Woronieckiego między innymi przez pracę wychowawczą i edukacyjną, której częścią jest analizowany przez nas dorobek. Wspomniane zależności między powołaniem zakonnym a pracą pedagogiczną, zapewne $\mathrm{w}$ ogóle dwustronne, pozostają poza zakresem naszych badań.

Wszystkie przytoczone przez nas fakty biograficzne pozwalają myśleć o Woronieckim jako o człowieku otwartego umysłu i szerokich horyzontów,

\footnotetext{
${ }^{7}$ Tamże.

${ }^{8}$ Zob. J. Woroniecki, O stosunku moralności..., dz. cyt.

${ }^{9}$ Zob. M. Niedziela, Kalendarium..., dz. cyt., s. 26.
} 
posiadającego zdolności organizacyjne i dużą wrażliwość duchową, odpowiedzialnym, zdolnym, pracowitym i skromnym. Ten wizerunek staje się jeszcze bardziej wyrazisty w trakcie poznawania tekstów jego autorstwa, gdy przed czytelnikiem odsłaniają się kolejne cechy osobowościowe Woronieckiego, znaczące $w$ pracy pedagogicznej. Wymieńmy je: patriotyzm i wyczucie aktualnych potrzeb wychowawczych polskiego społeczeństwa, roztropność i poczucie sprawiedliwości w szukaniu rozwiązań, cierpliwość i długomyślność w oczekiwaniu na rezultaty działań wychowawczych.

\section{Pedagogiczny charakter dorobku Woronieckiego: lata 1903-1918}

Musimy zaznaczyć, że udało się nam objąć analizą tylko jedenaście $\mathrm{z}$ dwudziestu sześciu prac Woronieckiego napisanych do $1918 \mathrm{roku}^{10}$. Ponadto dodajmy, że nie zbadaliśmy pokaźnej (przeszło osiemdziesiąt publikacji ${ }^{11}$ ) literatury przedmiotu. Przypomnijmy tylko, że pierwsza pozycja z długiej listy prac poświęconych myśli Woronieckiego jest datowana na rok 1916. Chodzi o recenzję publikacji Przewodnik po literaturze religijnej dla osób pragnących pogłębić swe wykształcenie $w$ dziedzinie wiary katolickiej wydanej przez Woronieckiego $\mathrm{w}$ roku $1914^{12}$. Wspomniana liczba prac komentujących i oceniających wypowiedzi Woronieckiego z jednej strony pokazuje proces zdobywania przez niego autorytetu pedagogicznego, a z drugiej pozwala nam przypuszczać, że wśród licznych komentarzy i ocen mogły się znaleźć odniesienia do tekstów Woronieckiego sprzed roku 1918. Zapoznanie się z tymi materiałami, aczkolwiek ciekawe dla naszego tematu, widzimy jednak jako odrębne zadanie badawcze.

Literatura poddana przez nas analizie, pomimo wspomnianych ograniczeń, jest na tyle zróżnicowana czasowo i tematycznie, że możemy podjąc się sformułowania wniosków o charakterze ogólnym. Zauważmy, że sięgnęliśmy do prac z lat 1903, 1906, 1911, 1914, 1916 i 1918 oraz że tematyka tych prac jest szeroka: polityczne zaangażowanie młodzieży, polska emigracja zarobkowa w Szwajcarii, zadania katolicyzmu w rzeczywistości dokonujących

10 Opieramy się na dwóch bibliografiach prac Woronieckiego: M. Filipiak, Bibliografia podmiotowa i przedmiotowa Jacka Woronieckiego OP, w: Człowiek - moralność - wychowanie..., dz. cyt., s. 277-297; M.B. Majewska, Wykaz pism o. Jacka Woronieckiego OP (do roku 1009Adama Woronieckiego) wydanych w latach 1903-2005, w: Stuga Boży..., dz. cyt., s. 157-174.

${ }^{11}$ Zob. tamże. Zauważmy, że w badaniach nad pedagogiczną myślą Woronieckiego rozważa się głównie cały dorobek tego myśliciela, nie wyodrębniając okresu, o którym piszemy w naszej analizie. Zob. na przykład J. Kostkiewicz, Kierunki i koncepcje pedagogiki katolickiej w Polsce 1918-1939, Kraków 2013, s. 97-128.

${ }^{12}$ Autorem wspomnianej recenzji jest ksiądz A. Pechnik. Recenzja ukazała się w „Miesięczniku Katechetycznym i Wychowawczym” 1916, 5, s. 321-322. Podaję za M. Filipiak, Bibliografia... dz. cyt., S. 293. 
się zmian społeczno-politycznych, na przykład rodzącego się na ziemiach polskich ruchu robotniczego, a ponadto problemy oświaty, religijności, wychowania, organizacji młodzieżowych, rodziny czy spraw związanych z przyszłością polskiego państwa, na przykład podpisanie konkordatu, szkolnictwo wyższe, edukacja religijna. Wszystkie wymienione tematy podkreślmy - Woroniecki rozważa w aspekcie moralnym, a to szczególne podejście naszym zdaniem niezaprzeczalnie nadaje jego pracom walor pedagogiczny. Ponadto omawiany przez nas dorobek posiada ogromny ładunek treści o charakterze edukacyjnym oraz różnych ustaleń istotnych dla kierunków i sposobów prowadzenia działalności edukacyjno-wychowawczej. Wymieńmy kilka najważniejszych spraw.

Przede wszystkim chcemy wskazać na kwestie działalności pedagogicznej jako takiej. Woroniecki - zauważmy - nie tylko wyróżniania, ale i łączy, na poziomie teoretycznych rozważań i praktycznych wskazówek, dwa wymiary konieczne w prowadzeniu człowieka do dojrzałości: wychowanie i edukację ${ }^{13}$. Oprócz tego wypowiada się z troską na temat różnych etapów kształcenia (od ludowego przez ogólnokształcące i zawodowe po szkolnictwo wyższe $)^{14}$ oraz zaznacza potrzebę prowadzenia studiów nauczycielskich: nauczyciel musi posiadać wysokie kwalifikacje merytoryczne $\mathrm{w}$ dziedzinie, której uczy ${ }^{15}$. Odnotujmy również, że pisze o różnych aspektach rozwoju człowieka $^{16}$ : poznawczym, moralnym, religijnym, fizycznym, ale przede wszystkim podkreśla wagę ich harmonizowania w wysiłku wychowawczym i samowychowawczym ${ }^{17}$.

Jak już zaznaczyliśmy, Woroniecki koncentruje się głównie na zagadnieniach ludzkiego postępowania: usilnie zabiega o właściwy poziom moralny człowieka, a wychowanie postrzega wręcz jako ważniejsze niż edukacja. Relacja wychowawcza ma według niego charakter osobowy i dlatego wymaga uwzględnienia zarówno podmiotowości wychowawcy, jak i wychowanka, a więc uznania odpowiedzialności obu stron zaangażowanych $\mathrm{w}$ wychowanie ${ }^{18}$.

${ }^{13}$ Zob. J. Woroniecki, Szkoła narodowa..., dz. cyt.; tegoż, Oświata i wychowanie, „Rok Polski” 1916, nr 7, s. 35-49; tegoż, Spoleczeństwo..., dz. cyt.

${ }^{14}$ Zob. tamże.

${ }^{15}$ Zob. tegoż, Uczeń..., dz. cyt.

${ }^{16}$ Zob. tegoż, Polscy obieżysasi w Szwajcarii, w: W kwestii wychodźstwa polskiego. Cztery rozprawy, Poznań 1906, 161-174; tegoż, O stosunku moralności..., dz. cyt.; tegoż, Szkota narodowa..., dz. cyt.; tegoż, Spoleczeństwo..., dz. cyt.; tegoż, O przyszłość ruchu skautowego..., dz. cyt.; tegoż, Uczeń..., dz. cyt.

17 Zob. tegoż, Przewodnik..., dz. cyt.; tegoż, Społeczeństwo..., dz. cyt.; O przyszlość ruchu skautowego..., dz. cyt.

${ }^{18}$ Zob. na przykład tegoż, Uwagi z powodu „Naszej Młodzieży” Scriptora. Odczyt wygłoszony w jednym z Towarzystwa Zjednoczonych, Lwów 1903; tegoż, Uczeń..., dz. cyt. 
Woroniecki stara się wyważyć $\mathrm{w}$ procesie wychowania wspomnianą relację wysiłku samowychowawczego i wychowawczego oraz podkreśla znaczenie czynników środowiskowych ${ }^{19}$. W wychowaniu dziecka niezastąpioną rolę pełni rodzina ${ }^{20}$. Nie bez znaczenia jest również działalność wychowawcza Kościoła21 czy szkoły ${ }^{22}$. Woroniecki dostrzega też wpływ grupy rówieśniczej na kształtowanie charakteru u młodych ludzi i stymulowanie procesów samowychowawczych, a w tym kontekście akcentuje potrzebę istnienia organizacji młodzieżowych ${ }^{23}$.

Następną ważną naszym zdaniem kwestią, która ukazuje pedagogiczny wymiar dorobku Woronieckiego, jest sposób, w jaki postrzega on związek rozwoju osobowego wychowanka z ksztaltowaniem postaw prospołecznych. Woroniecki zdecydowanie łączy formację wewnętrzną ze społecznymi zadaniami, które człowiek może podjąć w życiu. Odnotujmy jeszcze raz, że wszystkie analizowane przez nas prace są poświęcone tematyce społecznej, a jednocześnie - co dwukrotnie już podkreśliliśmy - wskazują na kwestie moralne i potrzeby kształtowania charakteru każdego człowieka.

Z perspektywy moralnej Woroniecki odnosi się do ukierunkowania wychowania na sprawy narodowe i obywatelskie ${ }^{24}$ oraz uwzględniania w nim sfery religijnej ${ }^{25}$. Religia - jego zdaniem - okazuje się niezastąpiona w ochronie wartości moralnych i obyczajów niezbędnych do utrzymania świadomości narodowej. Ponadto wprowadza w życie człowieka i społeczności perspektywę ponaddoczesną, która wskazując ostateczne cele ludzkiego życia, ochrania wolność indywidualną i narodową ${ }^{26}$. Zapewne dlatego w listopadzie 1918 roku, u progu odrodzenia polskiej państwowości, Woroniecki pisze o konieczności otoczenia opieką przez przyszłe państwo polskie przestrzeni religijnej i wyznaniowej w kulturze narodowej ${ }^{27}$.

${ }^{19}$ Zob. tegoż, Przewodnik..., dz. cyt.; tegoż, Spoleczeństwo..., dz. cyt.; O przyszlość ruchu skautowego..., dz. cyt.

${ }^{20}$ Zob. tegoż, Oświata..., dz. cyt.; tegoż, Społeczeństwo..., dz. cyt.; tegoż, O przyszłość ruchu skautowego..., dz. cyt.

${ }^{21}$ Zob. tegoż, Oświata..., dz. cyt.; tegoż, Spoleczeństwo ..., dz. cyt.; tegoż, Konkordat czy rozdziat, „Rok Polski” 1918, nr 6, s. 352-363; tegoż, O przysztość ruchu skautowego..., dz. cyt.

${ }^{22}$ Zob. tegoż, Oświata..., dz. cyt.; tegoż, Spoleczeństwo..., dz. cyt.; tegoż, O przyszłość ruchu skautowego..., dz. cyt.; tegoż, Uczeń..., dz. cyt.

${ }^{23}$ Zob. tegoż, O przyszłość ruchu skautowego..., art. cyt.

${ }^{24}$ Zob. tegoż, Uwagi..., dz. cyt.; tegoż, Historia Katolickiej akcji spolecznej w XIX wieku. Szkic historyczno-społeczny, Lublin 19o6; tegoż, Szkoła narodowa..., dz. cyt.; tegoż, Spoleczeństwo..., dz. cyt.; tegoż, O przysztość ruchu skautowego..., dz. cyt.

${ }^{25}$ Zob. tegoż, O stosunku moralności..., dz. cyt.

${ }^{26}$ Zob. tamże oraz tegoż, Konkordat..., dz. cyt.

${ }^{27}$ Zob. tegoż, Spoleczeństwo..., dz. cyt.; tegoż, Konkordat..., dz. cyt. 
Jak zaznaczyliśmy, narodowość jest ważnym czynnikiem, który według Woronieckiego powinien być brany pod uwagę w wychowaniu. Oprócz licznych uwag na temat kształcenia obywatelskiego (politycznego) młodzieży ${ }^{28}$ oraz realnego określenia narodowych „słabości” ${ }^{29}$ wśród analizowanych tekstów naszą uwagę zwrócił artykuł poświęcony nauczaniu języka polskiego ${ }^{30}$. Woroniecki dowodził w nim, że bez dostrzeżenia istotnej roli języka ojczystego w kształtowaniu życia umysłowego nie ma mowy o wysokim stopniu rozwoju polskiej kultury ${ }^{31}$. Ciekawe, że swoją argumentację sprowadził głównie do pokazania zależności między rozwojem wewnętrznym człowieka a kompetencjami językowymi.

Również kolejne kwestie pedagogiczne poruszane przez Woronieckiego są - naszym zdaniem - konsekwencją widocznego w jego tekstach łączenia zagadnień moralnych i społecznych oraz wagi, jaką przypisywał budzeniu w człowieku poczucia odpowiedzialności za własny rozwój. Na przykład z jednej strony podkreśla odpowiedzialność ludzi wykształconych, zaangażowanych politycznie za położenie najniższych warstw społecznych $^{32}$, a z drugiej dostrzega wagę wzbudzenia $\mathrm{w}$ tych warstwach potrzeby samokształcenia i samopomocy ${ }^{33}$. Zaznaczmy jednocześnie, że Woroniecki unika pustej retoryki, ale szuka realnych rozwiązań problemów w konkretnych warunkach społeczno-politycznych oraz że proponowane przez niego rozwiązania dostrzeganych problemów zawsze wiodą ścieżkami edukacji i wychowania.

Analizując dorobek Woronieckiego, zwróciliśmy także uwagę na miejsca wydania prac. Ten szczegół wydał się nam ważny w związku z tym, że omawiamy twórczość Woronieckiego do momentu, w którym Polska odzyskała niepodległość. Rozważane przez nas publikacje pochodzą z terenów trzech zaborów: sześć artykułów z krakowskiego miesięcznika „Rok Polski”, jeden z „Wiadomości Archidiecezjalnych Warszawskich” oraz dwa teksty wydane we Lwowie, jeden w Poznaniu, jeden w Lublinie. Zróżnicowanie, które nas zainteresowało, wiązało się prawdopodobnie z ograniczeniami wolności słowa wynikającymi z sytuacji politycznej, w jakiej znajdował się naród polski podczas zaborów, niemniej jednak uwzględnienie wspomnianych

\footnotetext{
${ }^{28}$ Zob. na przykład tegoż, Uwagi..., dz. cyt., s. 25. Woroniecki zauważa: „Gdybyśmy lepiej znali naszą przeszłość, jej wspaniałe momenta i potężne postacie, gdybyśmy bardziej przejmowali się tradycyą naszych jasnych i smutnych chwil, nabylibyśmy więcej szacunku dla tych, którzy tej przeszłości pracę swego życia poświęcili, sądzilibyśmy ich inaczej nawet tam, gdzie postępują oni wbrew naszym przekonaniom." Zobacz też: tamże, s. 18-20, 26, 28.

${ }^{29}$ Zob. tegoż, Spoleczeństwo..., dz. cyt., s. 55 .

${ }^{30}$ Zob. tegoż, Szkoła narodowa..., dz. cyt., s. 87-108.

${ }^{31}$ Zob. tamże, s. 107.

${ }^{32}$ Zob. tegoż, Uwagi..., dz. cyt.; tegoż, Historia ..., dz. cyt.; tegoż, Polscy obieżysasi..., dz. cyt.

${ }^{33}$ Zob. tegoż, Historia ..., dz. cyt.
} 
zróżnicowań pozwala przypuszczać nie tylko, że nazwisko Woronieckiego stawało się znane Polakom, ale że miał on także okazję poznawać potrzeby społeczne panujące w różnych zaborach, dzięki czemu jego myśl pedagogiczna nabierała cech realizmu. Prawdopodobnie łatwiej mu było w przyszłości, to znaczy w okresie Polski niepodległej, formułować wnioski dotyczące zadań edukacyjno-wychowawczych.

$\mathrm{Na}$ zakończenie tej części rozważań musimy wskazać na jeden wyjątkowy, a przywoływany przez nas wcześniej, tekst Woronieckiego: Przewodnik po literaturze religijnej... (1914). Mimo że praca może łatwo zostać zaklasyfikowana jako katechetyczna czy jako wyraz starań Woronieckiego o podnoszenie poziomu świadomości chrześcijańskiej Polaków, my chcemy widzieć w niej wyraźnie sformułowany i opracowany w szczegółach program edukacyjno-wychowawczy, oczywiście w dziedzinie religii. Stusześćdziesięciostronicowy Przewodnik... łączy w sobie wiele z wymienionych przez nas aspektów pedagogicznych myśli Woronieckiego, na przykład integralność wychowania, jego społeczny i obywatelski charakter, moralny obowiązek samokształcenia itp. Teoretyczne rozważania są w nim ukierunkowane na praktyczne rozwiązania wychowawcze.

Zauważmy, że na jasno sprecyzowany plan edukacyjny w Przewodniku... wskazuje układ zaproponowanej w nim i omówionej przez Woronieckiego bibliografii. Woroniecki zaleca, aby poznawanie przedmiotu wiary rozpocząć od zagadnień ogólnych dających ogląd całokształtu nauki chrześcijańskiej i związków między poszczególnymi jej częściami. Uzyskawszy tego rodzaju wprowadzenie, dzięki przestudiowaniu jednego z zaleconych dzieł dogmatycznych (Woroniecki proponuje pozycje krótsze i dłuższe), można dopiero przystąpić do poznawania bardziej szczegółowych problemów, na przykład istnienia i natury Boga, cudów, natury człowieka (przed grzechem i po nim), nieśmiertelności duszy, wolności woli, zagadnień z dziedziny moralności. Można wreszcie podjąć kwestie z zakresu religii objawionej, w tym chrześcijaństwa i samego wyznania katolickiego czy ustroju i historii Kościoła, rozwoju dogmatów itp. Woroniecki podkreśla, że gruntowne poznanie nauki chrześcijańskiej wymaga $\mathrm{w}$ pierwszej kolejności podjęcia studiów systematycznych. Proponuje więc zawsze zajmować się w drugiej kolejności lekturą pozycji apologetycznych, $\mathrm{z}$ natury swej prezentujących ujęcia jednostronnie, to jest ukierunkowane na konkretne aspekty wiary dyskutowane w danym momencie historycznym.

Przewodnik... jest adresowany do polskiej inteligencji początku XX wieku i pokazuje - jak już zaznaczyliśmy - zaangażowanie Woronieckiego $\mathrm{w}$ dzieło wychowywania religijnego i moralnego tej grupy społecznej. Woroniecki potrafił z jednej strony bardzo krytycznie oceniać jej poziom życia religijnego, a $\mathrm{z}$ drugiej moralnie ją zobowiązywał do realizacji bardzo 
wymagającego, jak można zauważyć, programu edukacyjnego. Dodajmy jeszcze, że w Przewodniku... znajdujemy nie tylko listę dzieł z różnych dziedzin służących do pogłębienia wiedzy religijnej, ale także uwagi na temat zebranej i uporządkowanej literatury. Napisane przez Woronieckiego późniejsze teksty, na przykład Szkola modlitwy czy Katolicka Etyka Wychowawcza, bez wątpienia są pracami, w których kontynuował zadanie podjęte w Przewodniku...: wychowywanie polskiej inteligencji w duchu wartości chrześcijańskich.

Przechodząc do kolejnej części naszych rozważań dodajmy, że wszystkie analizowane przez nas teksty są obszerne pod względem liczby stron i merytorycznie pełne treści. Oprócz wspomnianego Przewodnika... mają głównie charakter publicystyczny, niemniej jednak musiały być tworzone ze znajomością naukowego warsztatu badawczego i z poczuciem ogromnej odpowiedzialności za słowo. Podkreślmy: są wyważone, analityczne, pozbawione doktrynerstwa, stronniczości, rzetelne i krytyczne. Nierzadko główny problem podjęty $\mathrm{w}$ publikacji zostaje poprzedzony analizami historycznymi. Woroniecki nie był dyplomowanym pedagogiem, ale pisząc o wychowaniu i edukacji, wykazywał się nie tylko wiedzą teoretyczną, ale i praktyczną, a ponadto troską o dobro wspólne i osobistym zaangażowaniem w życie społeczno-polityczne polskiego narodu.

\section{Glówne myśli pedagogiczne w twórczości Woronieckiego: lata 1903-1918}

Problematyka wszystkich analizowanych przez nas prac Woronieckiego jest mocno osadzona w kontekście konkretnych uwarunkowań historycznych, niemniej jednak nie narusza to wagi ogólnych twierdzeń natury pedagogicznej, które w nich spotykamy. Możemy nawet stwierdzić, że dziś, gdy przeminęły problemy społeczno-polityczne, do których Woroniecki się odnosił, łatwiej dostrzec jego myśl pedagogiczną i znaleźć w niej inspirację do rozwiązywania aktualnych zagadnień edukacyjno-wychowawczych. Przechodząc do zapowiedzianego omówienia, zaznaczmy, że interesują nas kwestie najważniejsze ${ }^{34}$.

Zaczniemy od przyjętego przez Woronieckiego, a wspomnianego już w poprzedniej części naszej analizy, rozróżnienia wychowania i kształcenia. Kształcenie - jak zauważa autor - służy rozwojowi potencjału poznawczego

${ }^{34}$ Zapis bibliograficzny w tej i następnej części pracy zostanie sporządzany, o ile to możliwe, w oparciu o najbardziej współczesne wydania publikacji Woronieckiego ze względu na uwspółcześnioną pisownię i dostępność tekstów. Mamy na myśli trzy następujące książki: J. Woroniecki, Wychowanie człowieka. Wybór pism, Kraków 1961; tegoż, U podstaw kultury katolickiej, Lublin 2002; tegoż, W szkole wychowania. Teksty wybrane, Lublin 2008. 
człowieka, a wychowanie - doskonaleniu moralnemu, którego wyrazem jest ludzki charakter ${ }^{35}$. W obu dziedzinach procesy przebiegają $\mathrm{w}$ człowieku dwupoziomowo: zdobywanie sprawności (odpowiednio: moralnych lub poznawczych) i zdobywanie wiedzy (odpowiednio: wiedzy praktycznej lub teoretycznej $)^{36}$. W obu istnieje potrzeba stymulacji ze strony otoczenia i w obu chodzi ostatecznie o uzyskanie autonomii (samokształcenie i samowychowanie $^{37}$. Obie dziedziny odgrywają istotną rolę w rozwoju człowieka i - choć odrębne - są wzajemnie powiązane ${ }^{38}$. Woroniecki z jednej strony podkreśla, że praca nad charakterem wymaga przynajmniej elementarnego wykształcenia, a z drugiej zaznacza, że czynniki charakterologiczne zawsze dają o sobie znać $\mathrm{w}$ procesie edukacji. Oba procesy Woroniecki widzi jako zadania rozciągnięte na całe ludzkie życie i związane ze społecznymi rolami, które człowiek pełni ${ }^{39}$.

Wewnętrzna jedność całego procesu rozwojowego (wychowawczoedukacyjnego) jest warunkowana jednością bytową człowieka, a jego złożoność wiąże się $\mathrm{z}$ odrębnością dynamiki rozwoju w sferze kształcenia $\mathrm{w}$ stosunku do dynamiki rozwoju w sferze wychowania. O ile kształcenie rozwija się $\mathrm{w}$ kierunku pogłębiania różnorodności i specjalizacji, o tyle wychowanie ma na celu coraz głębszą wewnętrzną integrację człowieka, potrzebną do nadania spójności jego postępowaniu ${ }^{40}$. Te różnice decydują według Woronieckiego o pierwszeństwie działań wychowawczych przed edukacyjnymi i o rozłożeniu społecznej odpowiedzialności za rozwój dzieci i młodzieży: wychowanie jest przede wszystkim zadaniem rodziny, a edukacja - szkoły $^{41}$.

Szkoła i rodzina zasługują - zdaniem Woronieckiego - na szczególną troskę (bez naruszania autonomii ich działań) ze strony państwa i społeczeństwa ${ }^{42}$. Zwróćmy uwagę na dwa wyjaśnienia Woronieckiego. Pierwsze dotyczy potrzeby „klimatu społecznego”, w którym funkcjonuje rodzina: „Gruntowna kultura obyczajowa, na religii i życiu narodowym oparta, jest tu tą konieczną podstawą, bez której rodzina nie jest w stanie wypełniać

${ }^{35}$ Zob. tegoż, Oświata a wychowanie, w: tegoż, W szkole wychowania, dz. cyt., s. 29-30.

${ }^{36}$ Zob. tamże oraz Szkoła narodowa a nauczanie języka polskiego, w: tamże, dz. cyt., s. 88.

${ }^{37}$ Zob. tegoż, Oświata a wychowanie, dz. cyt., s. 32.

${ }^{38}$ Zob. tamże oraz tegoż, Spoteczeństwo a wychowanie, w: tegoż, W szkole wychowania, dz. cyt., S. 51.

${ }^{39}$ Zob. tamże, s. $45-47$.

${ }^{40}$ Zob. tegoż, Oświata..., dz. cyt., s. 33-35,

${ }^{41}$ Zob. tamże, s. 37-39.

${ }^{42}$ Zob. tamże, s. 37 oraz tegoż, Społeczeństwo..., dz. cyt., s. 45-47 oraz tegoż, O przyszłość ruchu skautowego, dz. cyt., s. 455 . 
swoich zadań wychowawczych" ${ }^{\text {*3 }}$. Drugie wskazuje na skutki zaniedbań wychowawczych w rodzinie: „Źle wychowanej w domu młodzieży szkoła nie przerobi radykalnie, tym bardziej, że i sama swój personel nauczycielski czerpać będzie $\mathrm{w}$ tym środowisku, w którym niedomagania wychowania rodzinnego tak bardzo dają się odczuwać brakiem silnie wychowanych charakterów"44.

Przytoczone fragmenty wskazują także na inne ważne treści pedagogicznej myśli Woronieckiego omawiane w poprzedniej części naszej analizy: przypisywanie znaczącej roli $\mathrm{w}$ wychowaniu czynnikom religijnym i narodowym oraz precyzowanie celu wychowania, jakim jest kształtowanie (silnego!) charakteru. Spośród wymienionych zatrzymamy się nad treściami, które dotyczą obecności religii w wychowaniu.

Rola religii w wychowaniu polega według Woronieckiego głównie na przekazywaniu wartości oraz na wskazywaniu ostatecznego celu ludzkiego życia ${ }^{45}$. Ukonkretnienie treści wychowawczych dokonuje się ze względu na kryterium wyznaniowe ${ }^{46}$. Możemy więc zauważyć, że model wychowania, który proponuje Woroniecki, jest otwarty na religię dwuwymiarowo. Po pierwsze, Woroniecki wskazuje $\mathrm{w}$ wychowaniu kierunek religijny jako taki, wiążąc go z doskonaleniem moralnym i kształtowaniem postaw tolerancji wobec wierzących ${ }^{47}$. Po drugie, widzi potrzebę włączenia $\mathrm{w}$ wychowanie konkretnego czynnika wyznaniowego. Samego Woronieckiego interesuje wychowanie w duchu wartości chrześcijańskich w formule katolickiej ${ }^{48}$.

Najogólniej mówiąc, w tekstach Woronieckiego dotyczących wychowania $\mathrm{w}$ świetle wiary mamy do czynienia $\mathrm{z}$ uzasadnieniami o charakterze teologicznym, dla których najbardziej znacząca jest dwuwymiarowość procesu wychowania: wychowawcą jest nie tylko człowiek, ale i Bóg ${ }^{49}$. Perspektywa chrześcijańska ustala zakres obowiązków i odpowiedzialności: człowiek (tj. wychowawca, wychowanek) ma być otwarty na działanie Boga i przed Bogiem jest odpowiedzialny za wychowanie (samowychowanie). Woroniecki, troszcząc się o rozwój religijności człowieka, zachęcał - jak podkreślaliśmy wcześniej - do wysiłku edukacyjnego. Dodajmy teraz, że również napominał, aby pobożność opierała się na mocy, która płynie

${ }^{43}$ Tamże, Oświata..., dz. cyt., s. 38.

${ }^{44}$ Tamże, s. 40.

${ }^{45}$ Zob. tegoż, Moralność a religia, w: tegoż, U podstaw kultury katolickiej, Lublin 2002, s. 58 65. (Tekst został wydany w roku 1935, a wcześniej był opublikowany w „Wiadomościach Archidiecezjalnych Warszawskich" w 1911 roku pod tytułem: O stosunku moralność do religii).

${ }^{46}$ Zob. tegoż, Przewodnik..., dz. cyt.

${ }^{47}$ Zob. tegoż, Moralność a religia, dz. cyt., s. 58-65 oraz tegoż, Konkordat..., dz. cyt. s. 361 i nn.

${ }^{48}$ Zob. tegoż, Moralność a religia, dz. cyt., s. 67-70.

${ }^{49}$ Zob. tegoż, Przewodnik..., dz. cyt., s. 59-6o i 64. 
z rzeczywistego związku człowieka z Bogiem - osi całego życia religijnego ${ }^{50}$. Postulował przy tym praktykowanie wiary rozumnej: ostrożnej wobec racjonalistycznej krytyki i pulsującej „myśleniem z Kościołem”51.

Zanim przejdziemy do kolejnej części naszych rozważań, dodajmy jeszcze, że wszystkie podejmowane przez Woronieckiego kwestie (od edukacyjnych przez polityczne po religijne) zakładały koncepcję wychowania, która polega na kształtowaniu charakteru $\mathrm{w}$ kierunku aretologicznym ${ }^{52}$. W duchu klasycznej teorii cnót Woroniecki postrzegał między innymi związek indywidualnych i społecznych aspektów wychowania. Człowiek - pisał - nie jest trybem w społecznej maszynie, chociaż bez społeczności nie spełnia się w swoim człowieczeństwie ${ }^{53}$. Sztuka wychowania to zarazem sztuka budowania relacji międzyosobowych.

\section{Specyfika pedagogicznej myśli Woronieckiego}

W refleksji nad całą spuścizną Woronieckiego najczęściej wskazuje się na tomistyczny fundament jego pedagogiki ${ }^{54}$. Składają się na niego głównie treści antropologiczne $\mathrm{w}$ zakresie filozofii i teologii oraz filozoficzny sposób prowadzenia refleksji, typowy dla filozofii przedkartezjańskiej. Warto w związku z tym podjąć również w naszych rozważaniach ten wątek: zapytać o tomistyczny charakter dorobku Woronieckiego w interesującym nas okresie, czyli do 1918 roku. Podkreślmy, że skoncentrujemy się na stronie filozoficznej tomizmu oraz że pominiemy problem miejsca przypadającego Woronieckiemu we współczesnym tomizmie (tzw. neotomizmie) - nurcie złożonym i dynamicznie rozwijającym się za jego życia ${ }^{55}$. Zaznaczmy tylko, że tomizm Woronieckiego ksztaltuje się w ramach odnowy tradycji neoscholastycznej, która dokonuje się między innymi pod wpływem encykliki Leona XIII Aeterni Patris (1879).

Na wstępie tej krótkiej analizy trzeba zauważyć, że Woroniecki dla potwierdzenia swojej argumentacji nigdzie wprost nie odwołuje się do pism św. Tomasza z Akwinu, co jest zrozumiałe ze względu na (głównie) publicystyczny i edukacyjno-wychowawczy charakter jego tekstów. Nie jest

${ }^{50}$ Tamże.

${ }^{51}$ Tamże, s. 19.

${ }^{52}$ Zob. tegoż, Szkoła narodowa..., dz. cyt., s. 101-102; tegoż, Oświata..., dz. cyt., s. 35-37; tegoż, Spoleczeństwo..., dz. cyt., s. 55; tegoż, Moralność a religia, dz. cyt., s. 59-60; tegoż, Przewodnik..., dz. cyt., s. 6o; tegoż, Uwagi..., dz. cyt., s. 18-20; tegoż, Historia..., dz. cyt., s. 49 i nn.; tegoż, O przyszłość ruchu skautowego, dz. cyt., s. 458 i nn.

${ }^{53}$ Zob. tegoż, Spoleczeństwo..., dz. cyt., s. 47.

${ }^{54}$ Zob. na przykład zbiór artykułów w: Człowiek - moralność - wychowanie..., dz. cyt.

${ }^{55}$ Zob. na przykład analizy M.A. Krąpca poświęcone kierunkom w tomizmie od XIX w: tegoż, Poznawać czy myśleć. Problemy epistemologii tomistycznej, Lublin 1994, s. 8-229. 
także zainteresowany sprawą wyjaśniania czytelnikom słuszności skomplikowanych i szczegółowych rozwiązań filozoficznych - najprawdopodobniej również ze względu na wspomniany charakter tekstów. W sumie w publikacjach z lat 1903-1918 zasadniczo nie spotykamy otwartej, merytorycznej dyskusji z innymi stanowiskami filozoficznymi. Mamy natomiast do czynienia z wyraźnym dystansowaniem się od tych, które zdaniem Woronieckiego są wychowawczo niebezpieczne. Zrozumienie pozycji światopoglądowej Woronieckiego - jako autora interesujących nas tekstów wymaga więc uwzględnienia nie tylko kwestii wyznaniowych (Woroniecki jest katolikiem), ale jakichś tez filozoficznych, które traktuje on jako narzędzie w swojej argumentacji pedagogicznej. Na przykład oceniając nowy nurt kultury, jakim był modernizm, Woroniecki krytycznie odnosi się do immanentyzmu, agnostycyzmu i pragmatyzmu ${ }^{56}$. Możemy przypuszczać, że narzędziem, o którym mowa, był tomizm. Spróbujemy to krótko wykazaćc ${ }^{57}$. Najpierw jednak na moment powrócimy do biografii Woronieckiego, by wskazać czynniki znaczące dla jego intelektualnej formacji.

Zauważmy, że tomizm był system filozoficzno-teologicznym, z którym Woroniecki zetknął się jeszcze na studiach w Szwajcarii (1898-1902) i który dalej zgłębiał jako dominikanin ${ }^{58}$. Woroniecki bez wątpienia wykazywał się wielką kulturą filozoficzną: posiadał wiedzę także w zakresie historii filozofii i stosował ją w swoich pedagogicznych rozważaniach ${ }^{59}$. Ponadto możemy przypuszczać, że jego zabiegi o pogłębianie życia religijnego, o wychowywanie

${ }^{56}$ Zob., na przykład J. Woroniecki, Przewodnik..., dz. cyt. Zob. także uwagi Woronieckiego na temat stanowisk w dziedzinie etyki - tegoż, Moralność a religia, dz. cyt., s. 66-67 oraz krótki rys na temat historii nowożytnej myśli filozoficznej i jej wpływu na kształtowanie stanowisk w dziedzinie teorii wychowania - Oświata..., dz. cyt., s. 23-27.

${ }^{57}$ W naszych analizach będziemy korzystać z głównie z tekstu Sumy teologicznej św. Tomasza z Akwinu w wydaniu skróconym: Tomasz z Akwinu, Skrót zarysu teologii (Sumy teologicznej) św. Tomasza z Akwinu, red. (skrót i objaśnienia) F.W. Bednarski, Warszawa 2000 (stosujemy ogólnie przyjęty skrót Sth.) oraz tegoż, O prawdzie, tłum. A. Białek, opr. M.A. Krąpiec OP i A. Maryniarczyk SDB, red. A. Maryniarczyk, Lublin 1999 (stosujemy ogólnie przyjęty skrót De Ver.). Ponadto będziemy korzystać z wybranych tekstów współczesnych tomistów. Poczynione przez nas uwagi można także porównywać z tekstami takich historyków filozofii, jak S. Swieżawski i É. Gilson. Zob. S. Swieżawski, Dzieje europejskiej filozofii klasycznej, Warszawa-Wrocław 2000, s. 643-703; É. Gilson, Tomizm. Wprowadzenie do filozofii św. Tomasza z Akwinu, tłum. J. Rybalt, Warszawa 1998.

${ }^{58}$ Zob. M. Niedziela, Kalendarium..., dz. cyt. Niedziela pisze: „Nie ulega wątpliwości, że młodego księcia [Woronieckiego - wyjaśnienie autorki] zafascynował tam [uniwersytet we Fryburgu M.M.B.] tomizm, i to zarówno jako system filozoficzno-teologiczny, jak i środowisko uprawiające tę dyscyplinę wiedzy." - tamże, s. 17. Zob. także: tamże, s. 23 i nn.

${ }_{59}$ Zob. na przykład J. Woroniecki, Uczeń..., dz. cyt. Woroniecki przytacza tekst z Platońskiego Fajdrosa, aby wyjaśnić rolę języka w rozwoju umysłowym człowieka - tamże, s. 111-113; zob. także, słowa Woronieckiego, które rozpoczynająjego krótki wywód filozoficzny: „Sprowadzenie moralności do samej wiadomości o tym, co dobre, a co złe i, co za tym idzie, wychowania do uświadamiania o obowiązkach, jest stare jak filozofia." - tegoż, Oświata..., dz. cyt., s. 23. 
patriotyczne i obywatelskie Polaków, były odpowiedzią na apel zawarty we wspomnianej encyklice Aeterni Patris, by podjąć dyskusję z nowymi ideologiami ( $\mathrm{z}$ indywidualistycznym liberalizmem i kolektywistycznym socjalizmem) właśnie w oparciu o Tomaszową antropologię.

Wypunktowanie tomistycznych cech tekstów Woronieckiego publikowanych do 1918 roku zaczniemy od typowej dla tomizmu sapiencjalnej perspektywy analiz. Woroniecki pisze właśnie z takiej, to jest mądrościowej, pozycji $^{60}$. Zabiega więc w swoich analizach o uchwycenie istoty jakiegoś faktu, zjawiska, pojęcia i dopiero w świetle tych ustaleń buduje dalszą argumentację na temat określonego sposobu rozwiązywania problemów społecznych, wychowawczych i edukacyjnych ${ }^{61}$. W ten sposób uzyskuje „neutralny grunt” potrzebny $\mathrm{w}$ dyskusjach społecznych: usuwa niejasności, rozprasza obawy dotyczące dyskutowanych kwestii oraz rzeczowo, a nie emocjonalnie, wykłada swoje poglądy na temat wychowania i edukacji ${ }^{2}$.

Kolejną cechą tekstów Woronieckiego jest charakterystyczna dla filozofii św. Tomasza analityczność. Dzięki niej Woroniecki sprawnie łączy kwestie teoretyczne z praktyką społeczną. Nigdy nie zatrzymuje się na opisie zjawiska, ale zmierza do określenia jego natury i istotnych przyczyn. $\mathrm{Na}$ początku rozważań zawsze dba o jasność pojęciowych rozróżnień, a następnie przechodzi do formułowania wniosków bardziej syntetycznych, które pozwalają na podjęcie konkretnych postanowień $\mathrm{w}$ dziedzinie praktyki wychowania i oświaty ${ }^{63}$. Obserwujemy więc $\mathrm{w}$ tekstach Woronieckiego charakterystyczne dla filozofii myślenie o wysokim stopniu ogólności, które jednak nie odcina myśli pedagogicznej od rzeczywistości społecznej, ale dzięki

${ }^{60}$ Zob. na przykład tamże, s. 25. Woroniecki w następujący sposób ocenia współczesną filozofię moralną: „Mści się tu oderwanie psychologii od metafizyki. Ona jedna rozwiązując zagadnienie stosunku duszy do ciała, daje psychologii klucz do rozumienia funkcjonowania wszystkich władz natury ludzkiej, w których wspólny udział pierwiastka duchowego i materialnego tyle przedstawia trudności. Oderwana od metafizyki w XVII w. psychologia, klucza tego nie znalazła, stąd też i etyka, która musi się na niej opierać, straciła swą silną podstawę. Z nauki o wychowaniu stała się nauką o normach moralnych postępowania o bardzo wybitnym intelektualnym charakterze." Por. S. Kamiński, Nauka i filozofia a mądrość, w: tegoż, Jak filozofować?, Lublin 1989, s. 55-61. Kamiński pisze: „Tomasz z Akwinu zaś uważał, że metafizyka stanowi jakby naukowo usystematyzowaną mądrość teoretyczną" - tamże, s. 61.

${ }^{61}$ Zob. na przykład J. Woroniecki, Moralność a religia, dz. cyt., s. 63; tegoż, O przyszłość ruchu skautowego, dz. cyt., s. 462-463; tegoż, Konkordat..., dz. cyt., s. 353; tegoż, Szkoła narodowa..., dz. cyt.

${ }^{62}$ Zob. na przykład tegoż, Moralność a religia, dz. cyt., s. 55-65; tegoż, Spoleczeństwo..., dz. cyt., s. 51-53; tegoż, O przyszłość ruchu skautowego, dz. cyt.

${ }^{63}$ Zob. na przykład tegoż, Uwagi..., dz. cyt.; tegoż, Moralność a religia, dz. cyt., s. 57 nn.; tegoż, Oświata..., dz. cyt., s. 28-35; tegoż, Spoteczeństwo..., dz. cyt., s. 47-50, 55, 61; tegoż, Konkordat..., dz. cyt., s. 352, $361 \mathrm{nn}$.; tegoż, O przyszłość ruchu skautowego, dz. cyt., 462-463; tegoż, Szkota narodowa..., dz. cyt., s. 92, 94-95, 103. 
porządkowi teoretycznych ustaleń umożliwia rzeczowe odniesienie do konkretnych problemów sfery wychowania i edukacji.

W tekstach Woronieckiego możemy także dostrzec, charakterystyczny dla filozofii św. Tomasza, rys realizmu epistemologicznego i metafizycznego. Woroniecki zajmuje przecież określone stanowisko w kwestii wartości: sprzeciwia się relatywizmowi i traktuje zasady moralne jako ogólnie poznawalne, stałe, niezmienne, konieczne ${ }^{64}$. Ponadto uznaje poznanie zdroworozsądkowe za wartościowe ${ }^{65}$. Między innymi dzięki temu jego myśl pedagogiczna nie ma charakteru spekulatywnego, a jest „zanurzona” w aktualnej rzeczywistości społecznej i twórczo szuka najlepszych rozwiązań. Jednym słowem: jest wynikiem konkretnych problemów społecznopolitycznych, a nie konsekwencją a priori przyjętego modelu wychowawczoedukacyjnego.

Cechę refleksji Woronieckiego jest optymizm. Mimo ostrego i krytycznego spojrzenia na różne zjawiska społeczne stara się on dostrzegać $\mathrm{w}$ nich dobre strony i w oparciu o nie budować program działań wychowawczych $^{66}$. W tym podejściu ujawnia się $\mathrm{w}$ pewnej mierze charakterystyczny dla św. Tomasza metafizyczny realizm ${ }^{67}$. Mamy na myśli następującą Tomaszową tezę: wszystko, co jest, jest bytem-dobrem. Jej konsekwencją jest „pozytywny” punkt wyjścia do całej praktyki pedagogicznej: nie można opierać działania edukacyjnego i wychowawczego na braku dobra, ale wychodząc od dobra, należy z miłością uzupełniać dostrzegane braki.

Również $\mathrm{w}$ duchu filozofii Akwinaty przedstawiane są przez Woronieckiego kwestie relacji między moralnością i religią: „(...) religia roztacza swe skrzydła nad całą dziedziną moralności; każdy czyn moralnie dobry przez to, że jest zgodny z prawem natury ludzkiej, jest zgodny z wolą Bożą, która tę naturę ustanowiła i nadała jej stałe prawa; zaś każdy czyn

\footnotetext{
${ }^{64}$ Zob. na przykład tegoż, Moralność a religia, dz. cyt., s. 63. Por. Tomasz z Akwinu, Sth., 1-2, q. 96.

${ }^{65}$ Zob. na przykład J. Woroniecki, Oświata..., dz. cyt., s. 28. Por. wypowiedź M.A. Krapca, który pisząc o stanowisku realizmu epistemologicznego Tomasza, zauważa: „Zasady zdrowego rozsądku przyjęte ogólnie przez ludzkość zawierają same w sobie (w swej treści) pewność. Z tych zasad wywodzi się wszelkie (ogólne i szczegółowe) naukowe poznanie. Filozofia opiera się na tych zasadach nie dlatego, że są one w powszechnym użyciu u ludzi, lecz że posiadają same w sobie treść oczywistą, którą filozofia jako nauka precyzuje, systematyzuje i uzasadnia.” - tegoż, Realizm ludzkiego poznania, Lublin 1995, s. 54.

${ }^{66}$ Zob. na przykład J. Woroniecki, Uwagi..., dz. cyt., s. 2, 25, 6o; tegoż, Polscy obieżysasi..., dz. cyt., s. 163; tegoż, O przysztość ruchu skautowego, dz. cyt., s. 467.

${ }^{67}$ Zob. określenie dobra według Tomasza z Akwinu: De veritate, q. 21, a. 1, resp. Zob. także wypowiedź M.A. Krąpca wyjaśniającą tomistyczną koncepcje zła: „[zło - M.M.B.] nie stanowi (...) jakiejś pozytywnej bytowej natury. Wszystko, co istnieje, co jest bytem, jest dobrem. Zło - to tylko bytowy brak" - tegoż, Metafizyka. Zarys podstawowych zagadnień, Lublin 1978, s. 198 oraz fragment mówiący o wyodrębnieniu zła moralnego jako braku zgodności ludzkich decyzji (ludzkiego postępowania) z obiektywnymi regułami ludzkiego postępowania (moralności) - tamże, s. 202.
} 
moralnie zły, łamiąc prawa natury ludzkiej, sprzeciwia się woli Bożej i jest grzechem; każdy obowiązek, jako z prawa moralnego wypływający, jest zarazem obowiązkiem względem Boga, który nas zobowiązuje do zachowania praw, w naszej naturze złożonych" - pisze autor $^{68}$.

Sprawę stosunku sfery nadprzyrodzonej i przyrodzonej w wychowaniu Woroniecki, podobnie jak Tomasz, opiera na zasadzie komplementarności ${ }^{69}$. Formułuje następujące wnioski: moralność przyrodzona, aczkolwiek jest możliwa bez Objawienia chrześcijańskiego i stanowi konieczny fundament dla moralności rozwijającej się pod wpływem łaski, niemniej jednak nie wystarcza do zbawienia, i dlatego potrzebuje wzmocnienia ze strony moralności nadprzyrodzonej ${ }^{70}$.

Kontynuując naszą refleksję nad tomistycznymi cechami pedagogiki Woronieckiego, zwróćmy uwagę na elementy antropologiczne w jego tekstach. Cała koncepcja wychowania i kształcenia odwołuje się do koncepcji człowieka św. Tomasza. Mamy bowiem do czynienia z pojmowaniem człowieka jako bytu potencjalnego i psychofizycznego, który rozwija się poprzez nabywanie sprawności fizycznych, moralnych, poznawczych oraz religijnych, zdolnego do poznawania prawdy, w tym $\mathrm{w}$ sferze moralności i religii ${ }^{71}$. W swoich analizach Woroniecki często przywołuje kwestie struktury bytowej człowieka, na przykład wyjaśnia na czym polega doskonalenie duchowych władz człowieka ${ }^{72}$. W oparciu o to prowadzi dalsze ustalenia pedagogiczne, o których już wcześniej pisaliśmy, na przykład uzasadnia rozróżnienia między wychowaniem a kształceniem, podział obowiązków w dziedzinie wychowania i kształcenia, zależności między sferami kultury religijnej, moralnej i naukowej.

Dodajmy jeszcze, że Woroniecki tomistycznie ujmuje kwestię ludzkiej rozumności. Z jednej strony spotykamy $\mathrm{w}$ jego tekstach ujęcie antywoluntarystyczne (problem kształtowania się relacji rozumu i woli w ludzkim działaniu), a z drugiej antyracjonalistyczne (problem rozróżnienia funkcji rozumu w dziedzinie teoretycznej i praktycznej). Rozumność, według niego podobnie jak według Tomasza - okazuje się cechą najmocniej definiującą

\footnotetext{
${ }^{68}$ J. Woroniecki, Moralność a religia, dz. cyt., s. 59. Por. Św. Tomasz z Akwinu, Sth. 1-2, q. 19, a. 9.

${ }^{69}$ Zob. np.: J. Woroniecki, Moralność a religia, art. cyt., s. 56, 64-67, 70; Por. Tomasz z Akwinu, Sth., 1-2, q. 109; oraz rozważania św. Tomasza z Sumy teologicznej dotyczącej teologii moralnej. Tomasz omawia cnoty teologiczne i obyczajowe oraz pokazuje cnoty obyczajowe z perspektywy nadprzyrodzoności - tegoż, Sth., 2-2.

${ }^{70}$ Zob. J. Woroniecki, Moralność a religia, dz. cyt., s. 70. Por. Tomasz z Akwinu, Sth., 1-2, q. 62, a. 2.

${ }^{71}$ Zob. Tomasz z Akwinu, Sth., 1, q. 75-102 oraz tamże, 1-2 i 2-2.

${ }^{72}$ Zob. na przykład J. Woroniecki, Szkoła narodowa..., dz. cyt., s. 94-104. Por. Tomasz z Akwinu, Sth., 1-2, q. 57, 58, 59 .
} 
sposób ludzkiego bycia: poznanie jest czynnikiem istotnym nie tylko w edukacji ${ }^{73}$, ale $\mathrm{w}$ religii ${ }^{74} \mathrm{i}$ w moralności ${ }^{75}$. $\mathrm{Z}$ tym należy lączyć podejmowaną przez niego krytykę stanowiska sentymentalizmu (na przykład w dziedzinie wiary) czy znaczenie rozwoju intelektualnego dla rozwoju kultury narodowej ${ }^{76}$.

W tekstach Woronieckiego dostrzegamy także obecność wspomnianego Tomaszowego rozróżnienia na poznanie teoretyczne i praktyczne ${ }^{77}$. Znacząco wpływa ono na pojmowanie moralności jako dziedziny, która potrzebuje nie tylko edukacyjnych działan, ale przede wszystkim wychowywania sfery pożądawczej człowieka: woli i emocji ze względu na ich rolę w kształtowaniu ludzkich postaw. Woroniecki, najprawdopodobniej za Tomaszem, przyjmuje, że na czym innym polega pewność sądów w dziedzinie poznania teoretycznego, a na czym innym $\mathrm{w}$ dziedzinie poznania praktycznego $^{78}$. Warto dodać, że konsekwencją owego rozróżnienia jest problem wagi, jaką przypisuje kształtowaniu charakteru człowieka oraz jego protest wobec ograniczania dziedziny moralności do zasobu wiedzy „o tym, co dobre, a co złe i, co za tym idzie, wychowania do uświadamiania o obowiązkach" ".

Woroniecki definiuje charakter człowieka jako zespół cnót kontynuuje tym samym myśl Tomasza oraz całej tradycji filozofii starożytnej

${ }^{73}$ Zob. na przykład J. Woroniecki, Szkoła narodowa..., dz. cyt., s. 102-103; tegoż, Oświata..., dz. cyt., s. 33 i nn. Por. Tomasz z Akwinu, Sth., 1, q. 79, a. 2, 3

${ }^{74}$ Zob. J. Woroniecki, Przewodnik..., dz. cyt. Por. na przykład Tomasz z Akwinu, Sth., 1, q. 2.

${ }^{75}$ Zob. na przykład następujące teksty Woronieckiego: „Najbliższym źródłem, skąd rozum powinien prawa moralne czerpać, tą księgą praw, którą on zawsze ma pod ręką, jest rozumna natura ludzka, której odbicie każdy w sobie nosi. Nie wszystkie prawa bezpośrednio w niej wyczytać można. Jedne są tak wyraźnie wyryte, że każdy najprostszy umysł musi je dojrzeć, inne zaś bardziej są ukryte i wymagają pewnego procesu myślowego, aby ich związek z naturą ludzka dostrzec."- tegoż, Moralność a religia, dz. cyt., s. 62; Zob. także: tegoż, Oświata..., dz. cyt., s. 30 . Woroniecki zauważa: „(...) wraz z postępem pracy wychowawczej powinno iść coraz gruntowniejsze zrozumienie uzasadnienia praw moralnych (...) zaniedbanie pierwiastka rozumowego jest dla wychowania fatalne. (...) Z władz poznawczych szczególnie sam rozum musi zostać wyćwiczony $w$ kierowaniu życiem, wychowany do rządzenia, uzbrojony w roztropność, rozwagę, rozsadek.” Por. Tomasz z Akwinu, Sth., 1-2, q, 47-51.

${ }^{76}$ Zob. na przykład tekst Woronieckiego na temat znaczenia racjonalnego podejścia do kwestii języka ojczystego: „W walkach o zachowanie ducha narodowego, któreśmy prowadzili, w ostatnich pięćdziesięciu latach, sprawa języka ojczystego zajmowała jedno z naczelnych miejsc i naród dowiódł ogromnego przywiązania do mowy ojczystej. A jednak przywiązanie to okazało się bardziej oparte na uczuciu niż na rozumowych przesłankach (...)” - tegoż, Szkoła narodowa..., dz. cyt., s. 106.

${ }^{77}$ Zob. tegoż, Oświata..., dz. cyt., s. 29-39; por. Św. Tomasz z Akwinu, Sth., 1, q, 8o, a. 11.

${ }^{78}$ Zob. np., J. Woroniecki, Społeczeństwo..., dz. cyt., s. 50, 54. por. Św. Tomasz z Akwinu, Sth., $1-2$, q. 61-2,15.

79 Zob. na przykład słowa Woronieckiego: „Sprowadzenie moralności do samej wiadomości o tym, co dobre, a co złe i, co za tym idzie, wychowania do uświadamiania o obowiązkach, jest stare jak filozofia" - tegoż, Oświata..., dz. cyt., s. 23 oraz tamże, s. 29, 31; zob. także: tegoż, Moralność a religia, dz. cyt., s. 63; tegoż, Spoleczeństwo..., dz. cyt., s. 44 i nn. 
i średniowiecznej. Cnotę, zgodnie z tą tradycją, określa jako sprawność moralną. Kształtowanie charakteru dokonuje się, jego zdaniem, poprzez ćwiczenie władz moralnych (swego rodzaju ascezę). Dzięki ćwiczeniom uzyskują one określoną sprawność moralną w zastosowaniu do pewnej kategorii czynów, bo w trakcie ćwiczenia - jak zauważa Woroniecki - dochodzi do całkowitego opanowania danej władzy przez rozum i wolę ${ }^{80}$. W rezultacie łatwiej i z większą radością wykonywane są uczynki odnoszące się do danej cnoty $^{81}$.

Podsumowując zauważmy, że w świetle całej przedstawionej powyżej analizy zasadne jest uznanie tomistycznej specyfiki pedagogicznego dorobku Woronieckiego z lat 1903-1918. W związku z tym można również określić jego pedagogikę z tego okresu jako pedagogikę filozoficzną.

\section{Zakończenie}

Dorobek pisarski Jacka (Adama) Woronieckiego z lat 1903-1918 ma wyraźnie pedagogiczny charakter. Decyduje o tym przede wszystkim poruszana w tych tekstach problematyka oraz moralna perspektywa podejmowanych przez Woronieckiego rozważań.

Cechą właściwą pedagogicznej refleksji Woronieckiego jest jej nachylenie filozoficzne. Dzięki niej nawet teksty publicystyczne Woronieckiego, dotyczące konkretnych problemów społeczno-politycznych, posiadają walory mądrościowe i ponadczasowe. Obraz pedagogiki, który udało się nam odczytać, pokazał ją jako konsekwencję realizmu filozoficznego typowego dla stanowiska tomistycznego, z którym identyfikował się Woroniecki. Można powiedzieć, że w oparciu o filozoficzne i teologiczne źródła, przede wszystkim $\mathrm{z}$ zakresu antropologii, niejako na gorąco znajdował on rozwiązania problemów natury pedagogicznej. Pod koniec swojego życia zapisał je w naukowym studium Katolicka etyka wychowawcza, ale i wtedy jego pedagogiczna refleksja nie wynikała $\mathrm{z}$ a priori przyjętego modelu wychowawczo-edukacyjnego, ale opierała się na realistycznie odczytywanych perspektywach psychofizycznego rozwoju człowieka.

Streszczenie: W artykule podjęto analizę myśli pedagogicznej Jacka (Adama) Woronieckiego na podstawie jego publikacji z lat 1903-1918 w celu wykazania, że już w tym czasie należał on do grona znaczących polskich pedagogów. W związku z tym analizy koncentrowały się wokół czterech zagadnień: biografii pedagoga, pedagogicznego wymiaru jego tekstów, głównych pedagogicznych tez, które stawiał oraz filozoficznego (tomistycznego) charakteru jego rozważań. Przyjętą tezę uzasadniono na podstawie

${ }^{80}$ Zob. J. Woroniecki, Przewodnik..., dz. cyt., s. 60.

${ }^{81}$ Zob. tegoż, Przewodnik..., dz. cyt. s. 6 o. 
kolejno formułowanych wniosków. Mianowicie zwrócono uwagę na: (1) pedagogiczne kwalifikacje Woronieckiego; (2) związek pedagogicznej wymowy jego tekstów z przyjętym w nich moralnym kierunkiem rozważań kwestii społecznych; (3) pedagogiczne postulaty, na przykład harmonizowanie $\mathrm{w}$ rozwoju człowieka elementów wychowawczych i edukacyjnych, pojmowanie wychowania jako kształtowania charakteru, wychowawczej roli rodziny oraz religii, przynależności narodowej i środowiska społecznego; (4) zasadnicze tomistyczne cechy pedagogicznego pisarstwa, które określono na podstawie sposobu prowadzenia przez Woronieckiego analiz (na przykład dążenia do ujęcia istoty opisywanych faktów) oraz założeń epistemologicznych, metafizycznych i antropologicznych.

Słowa kluczowe: polska pedagogika katolicka, wychowanie, edukacja, charakter, tomizm 